\title{
RE-WRITING MYTH: AN ANALYSIS OF MARGARET ATWOOD'S THE PENELOPIAD
}

\begin{abstract}
Myths provide a fertile ground for adaptation and appropriation. The preoccupation of writers with the stories and characters from the margins leads to interesting variations of age-old stories. As a consequence, the familiar stories are re-worked and transformed as an act of subversion. The embedded mythical framework in the revised text enriches its meaning infinitely. This paper is an attempt to understand Atwood's text as trying to fill in some gaps in Homer's Odyssey. As a feminist writer, Atwood re-visits the canonical text from a new perspective. She attempts "not to pass on a tradition but break its hold over us" (Rich). The re-writing of grand narratives becomes a strategy whereby a shift in power becomes possible. Atwood's text is subtitled 'The Story of Penelope and Odysseus' making the shift quite clear. The narrative voice alternates between Penelope's disembodied spirit from the underworld and the chorus of her twelve, faithful maids. The Penelopiad, in this way, becomes a polyphonic text where the different voices blend and clash and no final, authoritative meaning is possible. The re-working, thus, becomes an act of liberation.
\end{abstract}

Keywords: adaptation; appropriation; Feminism; intertextuality; irony.

Myths provide a fertile ground for adaptation and appropriation as they enjoy a wide readership across cultures and generations. The preoccupation of writers with the popular stories and characters leads to interesting variations of age-old stories. Myths embody the cultural archetypes and are an expression of the collective unconscious. The characters have a strong hold on our minds and imagination. Julie Sanders points out that for reworking to be effective, the texts must be well known: "They need to serve as part of a shared community of knowledge, both for the interrelationships and interplay to be identifiable and for these in turn to have the required impact on their readership" (97). Roland Barthes also points out in Mythologies that "the fundamental character of the mythical concept is to be appropriated" (119). He further tells us that myths

* Doaba College, Jalandhar, Punjab; India. 
'ripen' as they spread. Transformation of the original story is a natural outcome when the myth is either transplanted in a new context or handled by a different author.

The idea of re-writing can be understood in terms of T S Eliot's 'historical sense'. For Eliot, "the historical sense involves a perception, not only of the pastness of the past, but of its presence" (16-7). He further thinks that a work of art has its complete meaning only in the context of the tradition of the past. The theories of intertextuality too have completely altered the concept of originality. A text is no longer an independent entity. Texts are bound to each other in a network of relationships where they create new texts in a never-ending process. Gerard Genette uses the term hypotext to signify the source text and the term hypertext to stand for the adapted version. He further tells us that texts have a 'palimpsestuous nature'. He observes: "Any text is a hypertext, grafting itself onto a hypotext, an earlier text that it imitates or transforms" (ix). As a consequence, the familiar stories are re-worked and transformed as an act of subversion. In some cases, the revised text can stand independently but the embedded mythical framework enriches its meaning infinitely.

A text is not a unified whole, but conceals a hole or an aporia that reveals its ideological underpinnings. It is the unsaid that carries more weight than the said. The privileging of one character at the expense of another is not a neutral activity but indicative of the author's power over their characters. What Terry Eagleton points out as a function of a critic also fits the role of a writer who rewrites a canonical text.

It is in the significant silences of a text, in its gaps and absences that the presence of ideology can be most positively felt. It is these silences which the critic must make 'speak'. The text is, as it were, ideologically forbidden to say certain things; in trying to tell the truth in his [sic] own way, for example, the author finds himself forced to reveal the limits of the ideology within which he writes. He is forced to reveal its gaps and silences, what it is unable to articulate. Because a text contains these gaps and silences, it is always incomplete. Far from constituting a rounded, coherent whole, it displays a conflict and contradiction of meanings; and the significance of the work lies in the difference rather than unity between these meanings...There is no central essence to it, just a continuous conflict and disparity of meanings. (34-5) 
Margaret Atwood strives to provide in The Penelopiad some answers to the gaps in the canonical text Odyssey. Odyssey is an epic and consequently written in an elevated style. Odysseus and his adventures are given most of the textual space. A canonical text is a source of undying fascination for writers. Porter Abbot uses the term 'master-texts' to describe those "stories that we tell over and over in myriad forms" (42). Odysseus is a warrior but he also has presence of mind and a cunning intelligence that makes him overcome the hardships that he encounters. For the ancient Greeks and for posterity, Odysseus is a figure worthy of emulation and reverence. However, in The Penelopiad, Atwood's treatment of Odysseus is that of sustained irony.

Odyssey is an ancient Greek poem attributed to the poet Homer. Composed around $700 \mathrm{~B} \mathrm{C}$, the poem is divided into 24 books. It recounts the adventures of the legendary hero on his journey back home after the Trojan War. The Trojan War had lasted for ten years; the journey to Ithaca lasts for another ten years. Most of the poem narrates the dangers that are encountered by Odysseus and his crew. Odysseus is the lone survivor among his crewmates. The epic poem begins in media res and the reader learns that Odysseus has been away from Ithaca for 20 years. Books 1-4 have been termed 'Telemacheia' as the theme is Telemachus' coming of age. Books 5-8 narrate his adventures with the beautiful nymph Calypso who has captured him on her island but frees him because of the intervention of gods. There are further adventures as he is shipwrecked by the sea god Poseidon on Phaeacia as a revenge for his son Cyclops' blinding. Books 9-12 recount Odysseus' adventures in the land of the Cicones and later in the land of the Cyclops. He also defeats Circe, becomes her lover and sails to the land of the dead. Odysseus and his men also arrive at the island of the Sungod Helios. At the end of this section, Odysseus is the only survivor left. Books 13-24 follow the great hero as he reaches Ithaca, slaughters the suitors who had been pestering his wife and feeding off his resources, and is reunited with his loving and patient wife Penelope.

Atwood attempts to retrieve the woman's story from a male-centred text. She gives voice to the silenced and marginalized characters that are only talked of, never seen. The narrative voice alternates between Penelope's disembodied spirit from the underworld and the chorus of her twelve, faithful maids. Penelope is impatient with the manner history has made her "An edifying legend. A stick used to beat other women with" (2). She feels suffocated in this role and wishes to scream that women should not follow her example. This is her 
rage at the obvious double standards imposed on women by patriarchy. She feels marginalized by Odysseus's power and compelled to sing his praises. She chooses silence over awkward questions.

Penelope feels that people have either venerated her or made her an object of ridicule in the stories they have made up about her: “...how they were turning me into a story, or into several stories, though not the kind of stories I'd prefer to hear about myself" (3). Impatient with the fact that she could not tell her own story or rectify what others were writing about her when she was alive, she wishes to spin a thread of her own. But she also realizes that she is a disembodied spirit now. Even if she spins a story, she'd find it difficult to put it across human listeners. All these doubts point to the difficulties women characters experience when they try to question their captivity in texts written by men.

Atwood's text gives voice to what has been repressed in Homer's text. She writes in the introduction to The Penelopiad that she' $\mathrm{d}$ always been haunted by the episode of the hanged maids. In book 22 of Odyssey, Odysseus orders Telemachus to kill the 12 maids who were closest to Penelope. Atwood further adds that there isn't sufficient explanation in Odyssey to account for this brutality. She gives narrative space to these 12 maids who form a chanting and singing chorus. The maids feel that they have been wronged and judged in a bad light. They also get the space to tell the story of their lives. The maids lament that they were either stolen or sold and had to slave for their masters from morning till night. They longed to be happy and learnt to manipulate and steal. The maids urge the gods to change their fate and send some prince to fall in love with them. They lament that only hard work and death is their destiny. The maids are hanged in Odyssey and their voices silenced forever. In The Penelopiad they scream for justice and express rage on being treated like dirt.

Atwood's text is a subversive take on Homer's Odyssey. There is a deliberate tone of irreverence as the narrator recounts the events. Penelope describes the Oracle as misunderstanding messages from gods as the latter often mumbled. In the underworld, the gods are shown devising punishments for people and playing jests with them. The gods are unable to keep their hands off mortal women; and the story of Leda and the swan is dismissed as concoction. Penelope wonders why Helen was never punished for causing so much death and destruction in the world whereas smaller crimes have been punished inordinately. The narrator describes the gods as messing up with the humans 
University of Bucharest Review $\propto$ Vol. XI/2021, no. 2 (new series)

Re-writing, Re-imagining the Past (IV)

and enjoying it. She calls them childish and nasty. Penelope also undermines the culture and traditions of the royal palace. She terms the wealth exchanged at the time of wedding as 'trash', 'sparkling wedding loot' and 'the pile of glittering junk'.

In Atwood's text, Odysseus hardly gets a flattering treatment. Penelope narrates that Odysseus makes a fool of her and gets away with it as well. He often plays his tricks and lies on her. Recollecting her first meeting with him, she points out that Odysseus was not considered a serious candidate for her hand even by the maids. He is described as a rustic and an upstart. On her wedding day, the suitors take part in a racing contest and Odysseus wins through cheating. "...I was being pawned off on an uncouth dolt who would haul me off to a dreary backwater" (30). Penelope narrates that after her marriage she "was handed over to Odysseus, like a package of meat. A package of meat in a wrapping of gold" (33). In an instance of self-irony, she narrates that the suitors who had lost did not fight afterwards: "It was more as if they'd failed to win an auction for a horse" (34).

Penelope confesses that she "had an inflated notion" (45) of Odysseus's capabilities. As becomes a king's daughter and a king's wife, her responses are constrained and conditioned by social expectations. She knows she has to enact a role while the reality is something else. In Penelope's narrative, Odysseus is a malingerer who feigns madness to avoid going to the Trojan War. The accounts of Odysseus's bravery are highly unreliable and contradictory. She strongly feels that minstrels have embroidered their narratives to present a highly exaggerated picture of Odysseus's bravery. Atwood's text supplies the information that is missing in Homer's text. Her narrative tells us about Penelope's ancestry especially her parents and cousin Helen. Atwood's attempt to add flesh to a character makes it easier to understand Penelope's nature and her choices. The term Gerard Genette uses for this is 'amplification'.

There are contradictions in Penelope's and the maids' narratives especially about the circumstances in which the maids were hanged. Penelope claims to be ignorant of the whole episode. In her version, these maids were almost like sisters and they assisted her in the task of unwinding the shroud. On the contrary, the maids enact a scene where two maids play the roles of Penelope and Eurycleia. In this enactment, Penelope gets scared on Odysseus's arrival. The 12 maids had assisted Penelope in smuggling the suitors to her room. According to the maids, Penelope and Eurycleia conspire to get them murdered so that 
Penelope's infidelity is not revealed.

Myths embody the power structures of a culture and help perpetuate it for posterity. The re-writing of grand narratives becomes a strategy whereby a shift in power becomes possible. Atwood's text is subtitled 'The Story of Penelope and Odysseus' making the shift quite clear. The Penelopiad, in this way, becomes a polyphonic text where the different voices blend and clash and no final, authoritative meaning is possible. There is no single, controlling narrative voice. The marginalized characters get as much textual space as the powerful. The reworking, thus, becomes an act of liberation.

Atwood's engagement with Homer can best be understood in terms of Adrienne Rich's essay: "Re-vision - the act of looking back, of seeing with fresh eyes, of entering an old text from a new critical direction... We need to know the writing of the past and know it differently than we have ever known it; not to pass on a tradition but to break its hold over us" (When We Dead Awaken 369). A sustained reworking and revision aims at constructing alternative points of view. Atwood's novel becomes a counter-discourse as it critiques Homer's canonical text. The Penelopiad testifies to Adrienne Rich's spirit of revolt to tradition and Julie Sanders' idea that infidelity to the original text makes for one of the most creative acts of adaptation and appropriation.

\section{Works Cited}

Abbott, H. Porter. The Cambridge Introduction to Narrative. Cambridge: Cambridge University Press, 2002.

Atwood, Margaret. The Penelopiad. New York: Penguin Books, 2014.

Barthes, Roland. Mythologies. Trans. Annette Lavers. London: Vintage, 1993.

Eagleton, Terry. Marxism and Literary Criticism. Berkeley: University of California Press, 1996.

Eliot, T.S. "Tradition and the Individual Talent". Selected Prose of T.S. Eliot, Ed. Frank Kermode. London: Faber, 1984.

Genette, Gerard. Palimpsests: Literature in the Second Degree. Trans. Channa Newman and Claude Doubinsky. Lincoln: University of Nebraska Press, 1997.

Homer. The Odyssey. Trans. E.V. Rieu. New York: Penguin Books, 1996.

Rich, Adrienne. "When We Dead Awaken". Feminisms: A Reader, Ed. Maggie Humm. Hemel Hempstead: Harvester Wheatsheaf, 1992. 
University of Bucharest Review $\approx$ Vol. XI/2021, no. 2 (new series)

Re-writing, Re-imagining the Past (IV)

Sanders, Julie. Adaptation and Appropriation. London and New York: Routledge, 2006. 